\title{
PENGARUH KECERDASAN INTELEKTUAL, KECERDASAN EMOSIONAL, DAN KECERDASAN SPIRITUAL TERHADAP KINERJA KARYAWAN DI TRANSFORMER CENTER KOTA BATU
}

\author{
Tirza Laura Angelica \\ (Program Studi Manajemen, Fakultas Ekonomi Universitas Kanjuruhan, Malang) \\ e-mail: tirzalaura@yahoo.com \\ Andi Nu Graha \\ Sri Wilujeng \\ (Program Studi Manajemen, Fakultas Ekonomi, Universitas Kanjuruhan, Malang)
}

\begin{abstract}
ABSTRAK : Mempertahankan tingkat kinerja karyawan sangat diperlukan terutama dalam proses pencapainan tujuan sebuah perusahaan, maka dalam penelitian ini dilakukan untuk menganalisis pengaruh kecerdasan intelektual, kecerdasan emosional, dan kecerdasan spiritual terhadap kinerja karyawan di Transformer Center Kota Batu. Penelitian ini mengambil 75 responden sebagai sampel dan menggunakan pengambilan sampel menggunakan teknik sampel jenuh. Alat analisis yang dipakai dalam penelitian ini adalah regresi linear berganda. Pengujian yang dilakukan yaitu dengan uji asumsi klasik, uji F, dan uji t. Hasil dari penelitian ini menjelaskan bahwa : (1) kecerdasan intelektual, kecerdasan emosional, dan kecerdasan spiritual secara bersamasama berpengaruh signifikan dan positif terhadp kinerja, (2) kecerdasan intelektual berpengaruh signifikan dan positif terhadap kinerja, (3) kecerdasan emosional berpengaruh tidak signifikan terhadap kinerja, dan (4) kecerdasan spiritual berpengaruh signifikan dan positif terhadap kinerja.
\end{abstract}

Kata kunci : kecerdasan intelektual, kecerdasan emosional, kecerdasan spiritual, kinerja

\section{PENDAHULUAN}

Pada era dewasa ini memiliki sumber daya manusia yang unggul akan berpengaruh pada cara perusahaan membuat sebuah kebijakan yang tepat agar dapat bersaing dengan perusahaan lain yang semakin kompetitif. Sebuah kebijakan yang telah dibentuk akan membantu dalam pengambilan keputusan disemua aspek yang ada dalam perusahaan. Aspek-aspek yang perlu diperhatikan oleh perusahaan dalam membuat sebuah kebijakan manajamen adalah kinerja sumber daya manusianya yang dapat dikelola dengan baik agar dapat meningkatkan produktivitas kinerja sumber daya manusianya tersebut, sehingga nantinya akan berdampak kepada kemampuan perusahaan dalam bersaing dengan perusahaan lain dan mampu mempertahankan kekokohan perusahaan. Memperhatikan tingkat kinerja karyawan sangat diperlukan terutama dalam proses pencapaian tujuan sebuah perusahaan. Wibowo (2007) menyatakan bahwa terdapat faktor-faktor yang dapat mempengaruhi kompetensi seseorang, yaitu: Karakterisik pribadi, Motivasi, Keyakinan, Kemampuan intelektual, dan Isu emosional. Setelah mendapatkan data dan pengolahan data didapat bahwa $69.6 \%$ karyawan Transformer Center masih berusia dibawah 30 tahun. Hal ini dapat mempengaruhi tingkat kecerdasan emosional karyawan dalam menjalankan aktivitas kerja sehari-hari. Terlebih dalam menghadapi beban kerja yang besar dibutuhkan kematangan emosi. Pembagian menurut pendidikan terakhir karyawan di Transformer Center setelah mendapatkan data dan mengolah data tersebut menunjukan bahwa 76,1\% karyawan di Transformer Center belum meraih gelar Sarjana atau masih dalam pendidikan SMA. Hal ini menunjukan bahwa masih perlunya peningkatan dari segi intelektual bagi para karyawan karena dalam melakukan tugas-tugas yang diberikan juga membutuhkan kecerdasan intelektual untuk menyelesaikannya. 
Transformer Center melihat dalam mengembangkan kecerdasan spiritual seseorang tidak hanya melalui kepercayaan mererka tapi juga dapat dikembangkan dari diri mereka sendiri agar dapat menjadi valuable person yaitu ahli bersyukur, ahli beramal, dan ahli dalam bertindak. Maka dalam kinerja karyawan ketika mereka memiliki kecerdasan spiritual yang bagus secara tidak langsung akan membuat mereka nyaman dalam bekerja. Berdasarkan latar belakang permasalahan yang telah diuraikan penulis dalam skripsi ini, maka penulis memfokuskan penelitian dengan judul "Pengaruh Kecerdasan Intelektual, Kecerdasan Emosional, Dan Kecerdasan Spiritual Terhadap Kinerja Karyawan Pada Transformer Center Kota Batu"

\section{TINJAUAN PUSTAKA \\ Kinerja}

Kinerja merupakan suatu hasil atau output dari setiap kegiatan yang dilakukan oleh seseorang dalam sebuah perusahaan berdasarkan pada tanggung jawab yang diberikan dengan tujuan tercapainya visi dan misi perusahaan serta dilaksankan dengan kemampuan, ketekunan, dan kemandirian merupakan sebuah kinerja yang dimiliki oleh seorang karyawan (Busro, 2018).

Busro (2018) menjelaskan bahwa kinerja seseorang dapat diukur berdasarkan 6 indikator yang dihasilkan dari pekerjaan yang bersangkutan. Keenam indikator tersebut adalah :

1) Kualitas, adalah kerja diukur dari tanggapan karyawan terhadap kualitas pekerjaan yang dihasilkan serta kesempurnaan tugas terhadap kemampuan karyawan.

2) Kuantitas, merupakan karyawan yang mampu mencapai hasil yang dinyatakan dalam nilai uang, jumlah unit, atau pekerjaan yang selesai.

3) Jangka waktu yang ditetapkan, adalah karyawan dapat menyelesaikan tugasnya pada awal waktu yang ditetapkan organisasi serta mampu mengoptimalkan waktu yang tersedia untuk kegiatan lain.

4) Kehadiran di tempat kerja, adalah bagaimana seorang karyawan dapat selalu hadir untuk mengerjakan setiap tugas dan tanggung jawab yang diberikan dengan tidak terlalu banyak meminta izin.

5) Sikap kooperatif di dalam organisasi, merupakan suatu sikap yang dimiliki seorang karyawan untuk dapat bekerja sama atau bekerja dalam tim dengan baik.

\section{Kecerdasan Intelektual}

Kecerdasan dalam arti umum adalah suatu kemampuan yang dibutuhkan untuk melakukan aktivitas mental dan berpikir, penalaran, dan pemecahan masalah. Kecerdasan intelektual umumnya disebut sebagai intelegensi. Intelegensi adalah kemampuan kognitif yang dimiliki individu untuk menyesuaikan diri secara efektif pada lingkungan yang kompleks dan selalu berubah. (Robbins, 2017). Tujuh indikator menurut Robbins (2017) dalam kecerdasan intelektual adalah :

1) Kecerdasan numeric adalah kemampuan dalam berhitung secara cepat dan tepat.

2) Kecerdasan verbal adalah kemampuan dalam hal memahami apa yang dibaca dan didengar.

3) Kecepatan presepsi adalah kemampuan untuk mengenali persamaan dan perbedaan visual dengan cepat dan tepat.

4) Penalaran induktif adalah kemampuan untuk mengenali suatu urutan logis dalam suatu masalah dan kemudian memecahkan masalah tersebut.

5) Penalaran deduktif adalah kemampuan dalam menggunakan logika serta menilai implikasi dari suatu argument.

6) Visualisasi spasial adalah kemampuan membayangkan bagaiman suatu obyek akan tampak jika seandainya posisinya dalam ruangan dirubah.

7) Daya ingat adalah kempuan untuk menahan dan mengenang kembali pengalaman di masa lalu.

\section{Kecerdasan Emosional}

Goleman (2009) menyatakan bahwa yang dimaksud dengan kecerdasan emosi adalah termasuk dalam kemampuan mengontrol diri, memacu diri agar tetap tekun, dan dapat memotivasi diri sendiri. Kecerdasan emosional sangat dipengaruhi oleh lingkungan, tidak bersifat menetap, dan dapat berubah-ubah setiap saat.

Goleman (2009) menempatkan kecerdasan pribadi Gardener dalam definisi dasar tentang emosional yang disebutkan sekaligus memperluas kemampuan ini menjadi lima komponen utama yang terdapat dalam teori kecerdasan emosional Goleman. Berikut kelima komponen utama tersebut: 
1) Self Awareness (Kesadaran Diri)

Mengetahui apa yang kita rasakan pada suatu waktu tertentu dan menggunakannya sebagai acuan dalam mengambil keputusan diri sendiri, memiliki tolok ukur yang realistis atas kemampuan diri dan kepercayaan diri yang kuat.

2) Self Management (Pengaturan Diri)

Menangani emosi yang kita miliki agar berdampak positif kepada pelaksanaan tugas, peka terhadap kata hati dan sanggup menunda kenikmatan sebelum tercapainya suatu sasaran, mampu pulih kembali dari tekanan.

3) Motivation (Motivasi)

Menggunakan hasrat yang dimiliki yang paling dalam untuk menggerakan dan menuntun menuju sasaran, membantu dalam mengambil inisiatif dan bertindak secara efektif dan untuk bertahan menghadapi kegagalan dan frustasi.

4) Social Awarness (Empati)

Merasakan apa yang dirasakan orang lain, mampu memahami mereka, menumbuhkan hubungan saling percaya dan menyelaraskan diri dengan bermacam-macam orang.

5) Relationship Management (Keterampilan Sosial)

Menangani emosi dengan baik ketika berhubungan dengan orang lain dan dengan cermat membaca situasi dan jaringan sosial, berinteraksi secara lancar, menggunakan setiap keterampilan untuk memengaruhi dan memimpin, berdiskusi dan menyelesaikan perselisihan dan untuk bekerja sama ataupun bekerja dalam tim.

\section{Kecerdasan Spiritual}

Zohar dan Marshal (2007) menjelaskan pengertian dari kecerdasan spiritual sebagai rasa moral, kemampuan menyesuaikan aturan yang kaku dibarengi dengan pemahaman dan cinta serta kemampuan dalam melihat kapan cinta dan pemahaman sampai pada batasnya, juga memungkinkan kita bergulat dengan ihwal baik dan jahat, membayangkan yang belum terjadi serta mengankat kita dari kerendahan. Dalam bukunya juga Zohar dan Marshall (2007) menjelaskan bahwa ketika seseorang memiliki kecerdasan spiritual yang bagus akan memiliki tanda-tanda sebagai berikut :

1) Kemampuan bersikap fleksibel, yaitu kemampuan yang dimiliki seseorang untuk dapat memposisikan diri dan menerima pendapat dari orang lain secara terbuka.

2) Tingkat kesadaran diri yang tinggi, yaitu suatu tingkat dalam kesadaran diri seseorang yang tinggi untuk dapat memahami visi dan tujuan hidupnya serta kemampuan seseorang untuk mengkritik dirinya sendiri.

3) Kemampuan untuk menghadapi dan memanfaatkan penderitaan, yaitu kemampuan untuk menghadapi serta memanfaatkan sebuah penderitaan, menghadapi dan menjadikan penderitaan sebagai sebuah motivasi untuk meningkatkan kualitas hidup dimasa depan, dan dapat selalu tersenyum serta bersikap tenang.

4) Kualitas hidup yang diilhami oleh visi dan nilai-nilai, yaitu sebuah kualitas hidup yang menggunakan visi hidup dan berpegang pada nilai-nilai hidup sebagai dasar untuk mewujudkan sebuah tujuan, seperti prinsip dalam pegangan hidup serta berpijak pada kebenaran

5) Kecenderungan untuk melihat keterkaitan antara berbagai hal (rendah hati), yaitu mampu untuk berpikir secara logis dan berlaku sesuai norma sosial.

6) Kecenderungan nyata untuk bertanya dan mencari jawaban-jawaban mendasar, kecenderungan untuk bertanya ini akan membuat dampak pada kemampuan dalam berimajinasi serta memiliki rasa ingin tahu yang tinggi.

\section{Hubungan Antar Variabel}

1. Hubungan Kecerdasan Intelektual, Kecerdasan Emosional, dan Kecerdasan Spiritual Dengan Kinerja Karyawan 
Banyak hal yang diperhatikan sebagai penilaian kompetensi bagi seorang karyawan ketika mereka akan bekerja disuatu perusahaan. Banyak test-test yang akan mereka lewati yang sengaja dilakukan oleh perusahaan dengan harapan dapat melihat kinerja seseorang tersebut setelah diterima di perusahaan. Test yang dilaksanakan seperti test tertulis dan wawancara pasti akan menyangkut akan aspek IQ dan EQ seseorang dan hasil test ini akan mempengaruhi pandangan perusahaan akan kinerja seorang karyawan ini. Maka dapat dilihat bahwa IQ dan EQ memiliki peranan penting dalam menentukan kinerja seseorang (Anastasi, 2010).

Keunggulan kompetensi seorang karyawan dalam hal IQ dan EQ harus diimbangi juga dengan memiliki SQ yang bagus, karena dalam hal ini SQ adalah bagaimana seorang karyawan memberi arti penting dalam hidup mereka lalu membawa arti spiritualitas tersebut dalam lingkungan kerja maka akan menjadikan mereka individu yang baik, sehingga berdampak pada hasil kinerja mereka (Akimas, 2016).

2. Hubungan Kecerdasan Intelektual Dengan Kinerja Karyawan

Ketika seseorang memiliki IQ yang tinggi diharpakan mampu menghasilkan kinerja yang bagus dibandingkan dengan seseorang yang memiliki IQ rendah. Hal ini dikarenakan ketika seseorang memiliki IQ yang tinggi ia akan memiliki kemampuan untuk menyerap ilmu yang ada dengan lebih mudah sehingga berdampak pada kemampuannya dalam menyelesaikan suatu masalah yang ada dalam pekerjaannya dengan baik (Robbins, 2017).

3. Hubungan Kecerdasan Emosional Dengan Kinerja Karyawan

Seseorang yang dapat mengontrol emosinya dengan baik maka akan menghasilkan kinerja yang baik pula. Dalam menghasilakan kinerja yang optimal kecerdasan emosi memiliki posisi yang sama pentingnya dengan kemampuan teknis dan analisis. Salah satu aspek dalam kecerdasan emosi adalah motivasi. Keberhasilan seseorang dalam memotivasi dirinya sendiri merupakan dasar untuk terwujudnya kinerja yang optimal dalam segala bidang (Goleman, 2009).

4. Hubungan Kecerdasan Spiritual Dengan Kinerja Karyawan

Kecerdasan spiritual merupakan perasaan yang terhubungkan dengan diri sendiri, orang lain, dan alam semesta secara utuh. Ketika seseorang bekerja, ia akan dituntut untuk mengarahkan intelktualnya, tetapi banyak hal yang membuat seseorang senang dalam melakukan pekerjaannya. Ketika seseorang memiliki kesempatan untuk mengekspresikan seluruh potensi diri yang dimiliki, maka secara tidak langsung ia akan memberikan kinerja secara maksimal. Hal tersebut akan muncul ketika seseorang itu memaknai setiap pekerjaannya dan dapat menyeimbangkan antara emosi, perasaan, dan otak.

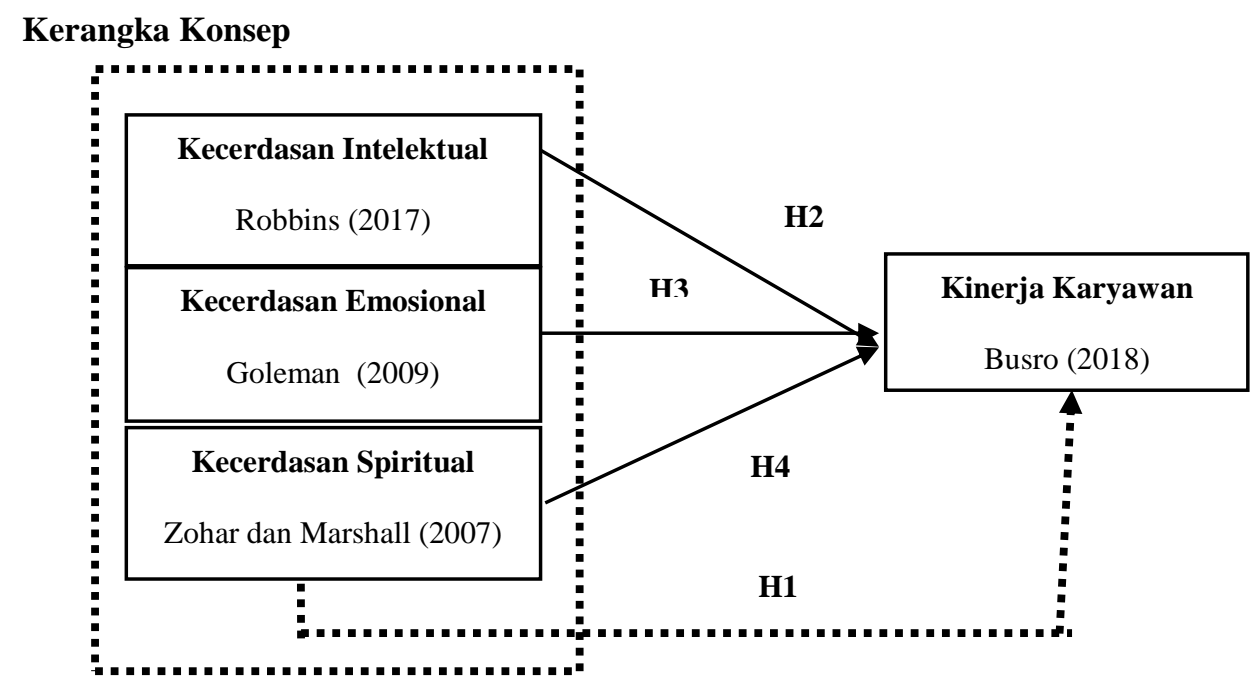

Keterarangan :

: Pengaruh secara parsial 
Hipotesis

1. H1 : Kecerdasan intelektual, kecerdasan emosional, dan kecerdasan spiritual mempunyai pengaruh signifikan terhadap kinerja

2. H2 : Kecerdasan intelektual mempunyai pengaruh signifikan terhadap kinerja

3. H3 : Kecerdasan emosional mempunyai pengaruh signifikan terhadap kinerja

4. H4 : Kecerdasan spiritual mempunyai pengaruh signifikan terhadap kinerja

\section{METODE}

\section{Rancangan Penelitian}

Penelitian ini menggunakan pendekatan kuantitatif dengan desain penelitian kausalitas. Pendekatan kuantitatif yang dipakai pada penelitian ini menggunakan metode observasi. Dalam menggunakan metode observasi, informasi dikumpulkan dari responden dengan menggunakan kuesioner. Pada metode observasi data untuk penelitian dikumpulkan melalui sampel dari populasi untuk mewakili seluruh populasi.

\section{Ruang Lingkup Penelitian}

Penelitian ini termasuk dalam ruang lingkup manajemen sumber daya manusia, bertujuan untuk menganalisis pengaruh yang menjelaskan hubungan antara variabel independen dengan variabel dependen. Dalam penelitian ini yang menjadi variabel independen adalah kecerdasan intelektual, kecerdasan emosional, dan kecerdasan spiritual, sedangkan untuk varibel dependennya adalah kinerja karyawan. Ruang lingkup penelitian ini berada pada PT. Berkat Terus Berlimpah atau yang dikenal dengan Transformer Center Jalan Raya Pandanrejo No 2 Kecamatan Bumiaji Kota Batu Jawa Timur.

\section{Populasi dan Sampel}

Populasi dalam penelitian ini adalah seluruh karyawan tetap yang ada pada Transformer Center Kota Batu yang berjumlah 75 karyawan. Pada penelitian jumlah sampel dapat dilakukan dengan berbagai teknik pengambilan sampel yaitu random sampel dan sampel jenuh. Dalam penelitian ini peneliti menggunakan teknik sampel jenuh dimana semua karyawan yang ada pada Transformer Center dijadikan sampel penelitian sebanyak 75 karyawan.

\section{Teknik Pengumpulan Data}

Dalam penelitian ini untuk teknik pengumpulan data terbagi menjadi dua jenis yaitu data kuantitatif dan data kualitatif. Untuk jenis data kuantitatif diambil dari data kuesioner yang didalamnya memuat juga tentang jumlah pegawai. Sedangkan untuk jenis data kualitatif diambil melalui wawancara yang mengasilkan data seperti sejarah singkat perusahaan, letak geografis objek, visi dan misi, struktur organisasi, keadaan pegawai dan karakteristik responden.

\section{Metode Analisis Data}

Uji regresi linear berganda bertujuan utuk memperkirakan serta memprediksi nilai rata-rata variabel dependen berdasarkan niali variabel independen yang ada. Regresi linearpun merupakan sebuah studi penelitian mengenai ketergantuang variabel terikat (dependen) dengan satu atau lebih variabel bebas (independen) (Ghozali, 2011).

$$
\mathrm{Y}=\propto+\beta 1 \mathrm{X} 1+\beta 2 \mathrm{X} 2+\beta 3 \mathrm{X} 3+\varepsilon
$$

$$
\begin{array}{cl}
\text { Keterangan : } & \\
\mathrm{Y} & : \text { Variabel dependen (Kinerja) } \\
\alpha & : \text { Konstanta } \\
\mathrm{X} 1 & : \text { Kecerdasan Intelektual (IQ) } \\
\mathrm{X} 2 & : \text { Kecerdasan Emosional (EQ) }
\end{array}
$$




$$
\begin{array}{ll}
\mathrm{X} 3 & : \text { Kecerdasan Spiritual (SQ) } \\
\varepsilon & : \text { Eror }
\end{array}
$$

Untuk menunjang uji regresi linear berganda dibutuhkan pengujian lainnya yang tidak kalah penting yaitu Uji

\begin{tabular}{|c|c|c|c|c|c|}
\hline \multirow[t]{2}{*}{ Model } & \multicolumn{2}{|c|}{$\begin{array}{l}\text { Unstandardized } \\
\text { Coefficients }\end{array}$} & \multirow{2}{*}{$\begin{array}{c}\begin{array}{c}\text { Standardized } \\
\text { Coefficients }\end{array} \\
\text { Beta } \\
\end{array}$} & \multirow[t]{2}{*}{$\mathbf{T}$} & \multirow[t]{2}{*}{ Sig } \\
\hline & $\mathrm{B}$ & Std. Eror & & & \\
\hline (Constant) & 1,681 & 5,310 & & ,316 & ,753 \\
\hline Kecerdasan Intelektual & 0,171 & 0,078 & , 188 & 2,191 &, 032 \\
\hline Kecerdasan Emosional & 0,022 & 0,065 &, 025 & ,334 & ,739 \\
\hline Kecerdasan Spiritual & 0,499 & 0,064 & ,668 & 7,836 & ,000 \\
\hline R Square $\left(\mathrm{R}^{2}\right)$ & ,596 & & & & \\
\hline Adjusted R Square & ,579 & & & & \\
\hline $\begin{array}{l}F \quad=34,937 \\
\text { Sig. } F=\quad, 000\end{array}$ & & & & & \\
\hline $\begin{array}{l}\mathrm{F} \text { tabel }=2,34 \\
\mathrm{~T} \text { tabel }=1,665\end{array}$ & & & & & \\
\hline
\end{tabular}
Validitas, Uji Reabilitas, Uji Asumsi Klasik, Uji F, dan Uji t.

\section{PEMBAHASAN}

1) Pengaruh kecerdasan intelektual, kecerdasan emosional, dan kecerdasan spiritual terhadap kinerja karyawan di Transformer Center Kota Batu

Melalui hasil tersebut dapat dijelaskan bahwa ketika kecerdasan intelektual, kecerdasan emosional, dan kecerdasan spiritual karyawan di Transformer Center digabungkan menjadi satu akan memiliki pengaruh yang signifikan dan memberikan efek yang positif terhadap kinerja mereka. Jadi ketika variabel bebas tersebut ditingkatkan atau dikembangkan secara bersama pula akan memberikan dampak yang lebih positif lagi pada kinerja pada karyawan tersebut. Tetapi nanti saat variabel bebas tersebut berdiri sendiri-sendiri akan memberikan pengaruh yang berbeda-peda terhadap kinerja karyawan di Transformer Center.

2) Pengaruh kecerdasan intelektual terhadap kinerja karyawan di Transformer Center Kota Batu

Dari hasil tersebut dapat menjelaskan bahwa kecerdasan intelektual dan kinerja di Transformer Center memiliki pergerakan yang searah, artinya ketika perusahaan ingin peningkatan dari kinerja karayawannya hal yang perlu dilakukan adalah dengan menambah nilai pada kecerdasan intelektual karyawan tersebut. Semakin tinggi kecerdasan intelektual karyawan di Transformer Center, maka akan berdampak pada kinerjanya yang semakin baik pula. Karena karyawan tersebut akan lebih mudah dalam menyerap pengetahuan yang ada lalu mengaplikasikannya pada cara menyelesaikan pekerjaan yang lebih baik.

3) Pengaruh kecerdasan emosional terhadap kinerja karywawan di Transformer Center Kota Batu

Dari hasil tersebut dapat menjelaskan bahwa kecerdasan emosional dan kinerja di Transformer Center tidak memiliki pengaruh yang signifikan, karyawan di Transformer Center dalam melakukan pekerjaan tidak terlau menggunakan kecerdasan emosional sebagai faktor pendukung.

4) Pengaruh kecerdasan spiritual terhadap kinerja karyawan di Transformer Center Kota Batu

Dari hasil tersebut dapat menjelaskan bahwa kecerdasan spiritual dan kinerja di Transformer Center memiliki pergerakan yang searah, artinya ketika perusahaan ingin peningkatan dari kinerja karayawannya hal yang perlu dilakukan adalah dengan menambah nilai pada kecerdasan spiritual karyawan tersebut. Semakin tinggi kecerdasan spiritual karyawan di Transformer Center, maka akan berdampak pada kinerjanya yang semakin baik pula. Karena karyawan tersebut akan lebih mudah dalam bersikap maupun dalam menerima pendapat orang lain untuk meningkatkan kinerjanya. 


\section{KESIMPULAN}

Penelitian ini memiliki tujuan yaitu untuk mengetahui pengaruh kecerdasan intelektual, kecerdasan emosional, dan kecerdasan spiritual terhadap kinerja karyawan di Transformer Center Kota Batu. Berdasarkan hasil dari analisis menggunakan regresi linear berganda serta pembahasan yang sudah dijelaskan, dapat ditarik kesimpulan sebagai berkut :

1) Kecerdasan intelektual, kecerdasan emosional, dan kecerdasan spiritual secra bersama-sama atau simultan memiliki pengaruh yang signifikan terhadap kinerja karyawan di Transformer Center Kota Batu.

2) Kecerdasan intelektual mempunyai pengaruh yang signifikan dan hubungan yang positif terhadap kinerja karyawan di Transformer Center Kota Batu.

3) Kecerdasan emosional tidak mempunyai pengaruh yang signifikan terhadap kinerja karyawan di Transformer Center Kota Batu.

4) Kecerdasan spiritual mempunyai pengaruh yang signifikan dan hubungan yang positif terhadap kinerja karyawan di Transformer Center Kota Batu.

\section{SARAN}

Untuk meningkatkan kinerja karyawan di Transformer Center kedepannya, perusahaan dapat memfokuskan pada kuantitas hasil kerja karyawan dengan mendorong karyawan agar menyelesaikan tugas sesuai jumlah yang ditetapkan dan meningkatkan progress hasil kerja. Selain itu untuk kecerdasan intelektual karyawan perusahaan dapat berfokus pada kemampuan penalaran karyawan secara induktif, dimana hal itu akan melatih kemampuan karyawan dalam memahami penyebab dari suatu masalah dan memecahkan permasalahan tersebut. Dilihat dari pembahasan sebelumnya karena kecerdasan emosional tidak berpengaruh secara signifikan, perusahaan tidak perlu terlalu berfokus pada hal-hal tersebut. Untuk kecerdasan spiritual perusahaan dapat meningkatkan kemampuan karyawan dalam menghadapi sebuah penderitaan atau dapat disebut sebuah permasalahan dan mampu untuk memanfaatkannya lalu membuat penderitaan tersebut sebagai motivasi Peneliti juga menyarankan untuk penelitian selanjutnya dapat meneliti tentang variabel-variabel lain yang tidak diteliti seperti adversity quotient, social quotient, creativity quotient, yang mungkin dapat menjadi faktor juga dalam meningkatkan kinerja karyawan.

\section{DAFTAR PUStaka}

Akimas, Nugroho Hari., dan Bachri, Alim Ahmad. 2016. Pengaruh IQ, EQ, dan SQ Terhadap Kinerja Pegawai Inspektorat Provinsi Kalimantan Selatan. Jurnal Wawasan Manajemen, 4 (3): 259-269.

Anastasi, Anne., dan Urbina, Susan. 2010. Tes Psikologi. Jakarta: PT. Indeks.

Busro, Muhammad. 2018. Teori-teori Manajemen Sumber Daya Manusia. Jakarta: Pernada Media Group.

Ghozali, Imam. 2011. Aplikasi Analisis Multivariate Dengan Program SPSS. Semarang: Badan Penerbit Universitas Diponegoro.

Goleman, Daniel. 2009. Emotional Intelligence : kecerdasan emosional mengapa EI lebih penting dari pada IQ. Jakarta: PT. Gramedia Pustaka Utama.

Robbins, P Stephen., dan Judge, A Timothy. 2017. Perilaku Organisasi. Jakarta: Salemba Empat.

Wibowo. 2007. Manajemen Kinerja. Jakarta: PT. Raja Grafindo Persada.

Zohar, Danah., dan Marshall, Ian. 2007. Spiritual Capital : Memberdayakan SQ di dunia bisnis. Bandung: Mizan Media Utama 